\title{
A Critique of Adjudication: Fin de Siecle
}

\section{Citation}

David W. Kennedy, A Critique of Adjudication: Fin de Siecle, 22 Cardozo L. Rev. 991 (2001) (reviewing Duncan Kennedy, A Critique of Adjudication: Fin de Siecle (1997)).

\section{Permanent link}

http://nrs.harvard.edu/urn-3:HUL.InstRepos:16121133

\section{Terms of Use}

This article was downloaded from Harvard University's DASH repository, and is made available under the terms and conditions applicable to Other Posted Material, as set forth at http:// nrs.harvard.edu/urn-3:HUL.InstRepos:dash.current.terms-of-use\#LAA

\section{Share Your Story}

The Harvard community has made this article openly available.

Please share how this access benefits you. Submit a story.

Accessibility 


\section{DUNCAN KENNEDY, A CRITIQUE OF ADJUDICATION: FIN DE SIËCLE}

\section{David Kennedy*}

"Duncan Kennedy is one of the most prominent and influential legal theorists of the day." I wanted to begin with a statement along these lines, and then I conveniently found this one in Bill Simon's blurb on the back cover of $A$ Critique of Adjudication: Fin de Siècle or, as I think of it, acronymically, ACOAFDS. I have probably read ACOAFDS two or three times since it came out, all the way through and in smaller bits, browsing and refreshing my recollection. Sometimes I'm looking for something specific-how did Duncan use the term "ideology," or "project," or "consciousness." Sometimes it's just entertainment, relaxing and listening to Duncan talk.

He's a great talker. Quite astonishing actually, especially when it just pours out. One of the great pleasures of being his friend is listening, even when he's not around, turning words around in my head and wondering what Duncan would say about something. And it's here I turn to ACOAFDS, to get the pump primed, triggering his voice. ACOAFDS is a kind of introject prosthetic.

After more than twenty years, Duncan's voice continues to fascinate me. Most any paragraph will do-here's one:

We don't get to the point of psychologizing American judges until we have decided that, at least for the moment, there's no sense in continuing our investigation of their views on the merits, because those views are wrong and, indeed, there is no sense in further dialogue with them on their own terms, because, for the moment, it is more interesting to figure out why they say what they say, on the assumption that it's wrong, than to investigate further whether it is wrong. It can be pretty infuriating to be treated this way....

Well, yes. And I recognize the run-on sentences, the abrupt tone shifts, the austere certainty. Duncan's voice can quiver with

* Henry Shattuck Professor of Law, Harvard Law School.

1 Duncan Kennedy, A Critique of Adjudication: Fin De SièCle, back cover (1997).

2 Id. at 198. 
zany elation and despair, can sound manic and juvenile and wise all at once. More often, his voice is didactic, interpretation dressed up as stark fact. Listen to this one:

The people who run institutions operate in bad faith in the same way judges do. On the one hand, they often experience their missions as sufficiently defined, given the practical circumstances, so that they are compelled to adopt particular strategies and reject others. To do anything else would be "unprofessional," a "breach of trust," "suicidal from the point of view of the bottom line," or whatever. On the other hand, they also manipulate the discourse of necessity to present all kinds of strategic choices that are not thus compelled as necessary and right. They constantly deploy their resources, they constantly work, just as judges do, to shape and reshape the necessity that they are supposedly merely submitting to. Competent "players" know this to be true, ... [b]ut the public discourse, as opposed to the back-room discourse of the organization, resolutely denies it. ${ }^{3}$

\section{LES IDÉES DE DUNCAN}

There are lots of ideas in ACOAFDS, ideas developed elsewhere in Duncan's work, and ideas sketched in for the first time. Of course there is an idea bundle about the relationship between adjudication and legislation, rules and standards, law and policy in American legal culture. How many times have I patiently explained the argumentative net that links rules with exceptions and standards or law with policy? And there it is in ACOAFDS, just as I first heard it, old favorites floating pleasantly in new amber. This time, as if for the first time, we find legislation and adjudication set up as avatars for the broader discursive system, and just how do they differ, let me see, you could say this, but no ... or perhaps this, but no, or not in that way exactly, but if you grant me this, then perhaps we can say... and so it goes through the volume.

For the last few years I have taught a course based on what I call a "canon" of American legal thought-from Holmes through Hohfeld, Hale, Dewey, and Frank and on to Fuller, Wechsler, Hart and Sacks, displaced in their turn by Coase, Calabresi, Macaulay, Galanter, and then Dworkin, Duncan, MacKinnon, and Crenshaw. You could draw up such a list in many ways, but it is striking how snugly ACOAFDS fits in the tradition of American jurisprudence, foregrounding private law materials, concerned about the plausibility of judicial argument and about the role of 
"policy" in American legal thought, reaching out to other disciplines in an eclectic search for methodological assistance.

In a way, the jurisprudential titans and theoretical big boys of this tradition are the book's real audience, and why not write for the dead? Flinch not; grab the brass ring, write a "critique of adjudication." It's bold, it's big, don't shy away from the biggest questions, from the choices of governing, from the exercise of power. At the same time, Duncan less stands on the shoulders of giants than chats with them across a long evening, offering us a window on his dinner with Lon. Duncan is not writing to be dead, to be recognized in the future as next in a line of wise dead men, but rather, I suspect, for the eye of the dead, for the experience and recognition now of belonging at their party. Or perhaps better, Duncan's imaginary readers are an audience engaged for the tradition's third eye, as if we were there so that Duncan might say to them, look, you explain it to people this way.

We think of American jurisprudence as a series of arguments about what law is, what judges do, how judicial actors should decide cases. ACOAFDS takes up lots of arguments about such things, takes them up by turns with earnestness, with interest, as if Duncan and his reader really did have infinite time, lost together behind a veil of, if not ignorance, at least plausible deniability or bemusement, gazing down at one or another argument from a great height, scotch clinking around in their glasses. But he can also rush in close and slash hard, either a single sardonic stroke, or something softer, cutting, mocking, giving way to a moral seriousness-how could respectable people argue like this?

Working his way among the classic arguments, Duncan foregrounds the astonishing quantity of critique in our traditionthe two-thirds of every article devoted to rejecting other people's ideas as one way or another too formal or too political. He recasts the tradition as a set of "viral" arguments about what law is not, what judges must not do, what arguments are not persuasive. And he offers an explanation for all this negation, a retelling of our legal culture as an emptying out of persuasion, treating governance, the legal allotment of stakes in society, as a sort of necessitarian residue from a determined practice of elite selfeffacement.

But how do they do it exactly? ACOAFDS develops Duncan's sociological vocabulary for depicting an intellectual elite on the job. They do "work," employing a variety of "materials" (doctrines, rules, prior cases, statutes, pieces of prior reasoning and criticism) to build effective "arguments" for and against outcomes. They do this in an institutional and social context, to be sure, but 
Duncan foregrounds a context of ideas, motives, and convictions, both conscious and unconscious. They participate in a professional "consciousness." They are affected by and produce "ideology." They pursue "projects" of ideology consolidation, and so forth. This idea context has effects on the work they do and on the disposition of stakes they effect-it channels, legitimates, moderates, and empowers.

\section{IN WHICH DUNCAN PEERS BETWEen THE SURFACE AND THE DEPTH}

ACOAFDS often treats the overt terms of the debate-rights, duties, claims about policy direction-like symptoms to be diagnosed rather than arguments to be engaged. There is an intellectual ethic here that disparages anything that seems mere surface, talking about anything that is not, as one might say about a spouse who insists on arguing about the toothpaste tube, "what is really going on." Of course sometimes symptoms really are important - they might be what we want to achieve or avoid, but they are also the tips of icebergs, the marks of great syndromes and maladies, political conflicts, characterological tendencies, and ideological commitments.

At the same time, however, Duncan loves the sparkle of the surface, would be happy to talk almost endlessly about the toothpaste tube, whatever. He goes out of his way not to speak of what lies beneath the sea:

My approach in what follows neither answers nor rejects, but rather defers or brackets, the question of what, if anything, lies behind ("in" the legal materials) the experiences of openness and closure. I think there is quite a bit we can say about judicial law making without an answer to this more ultimate question. We can explore the "surface," rather than trying to penetrate the depths. ${ }^{4}$

$\mathrm{He}$ is interested in what legal professionals sense vaguely about themselves and others, what they glimpse beneath the waves when sailing in icy waters, what they see beneath one another's boats, if not always their own, but don't usually say. He offers no explanation beyond that-there is nothing here about how icebergs form, how global warming or a captain's haste might make them ever more frequent and dangerous. It's not empiricism, and he's not asking why. But neither is he simply chatting along, "continuing [an] investigation of their views on the merits." Somehow Duncan writes about all the big jurisprudential

\footnotetext{
4 Id. at 171.

5 Id. at 198 .
} 
questions without offering either surface or depth. He is at once an exhibitionist in a world of stoic denial and a stoic in a land of babbling apology.

\section{DUNCAN AS PERFORMANCE ART}

I often turn to ACOAFDS to remember how Duncan manages not to say something. He doesn't say the rules, doctrines, and policy arguments are infinitely malleable. He doesn't claim to have a structuralist machine for aligning argument fragments or uncovering indeterminacy. He doesn't say adjudication is "just" legislation or that law is "just" politics. Indeed, hardly anything is "just" anything else in this description-instead, we find people struggling to do their work, overestimating closure and underestimating malleability. Duncan sketches them in with anecdotes, hypotheses, allegories. Above all, the work is description.

Duncan offers a description, not of how things "really are," but of how he really sees them; how they look, how they seem. He's looking at people, people thinking about law, working to produce legal arguments and rules. ACOAFDS offers a wordpicture aimed to persuade you to see them as Duncan does. In coaxing you there, he skirts right up to saying "this is just this" or "that is just that," and then he pulls back, gives room. Perhaps it's also the other way around. People often experience it differently-sometimes it seems they do, at any rate-so perhaps it could be like this, but it might be like that, my best description is this one, can you see it too? ACOAFDS places the reader at Duncan's side, wandering about among the legal elites, chatting with him, as they come upon one after another befuddled adjudicator or struggling jurisprud.

Both-both Duncan and the reader-take the adjudicator's own experience as a touchstone; this is a consciousness we are expounding, and it won't do to substitute our own ideas or theories, however elegant. There is much in the voice that is deferential, abject-Duncan is your humble servant, explaining, taking seriously, doing the work of navigation and map making, describing things as others experience them. And yet, of course, you and I, dear reader, know it is a rare judge who truly knows himself, know that the picture we are building here may well be a far better account of our judge's own experience than anything he might come up with. We might even expect, hope, the judge would agree if you could get him/her in an unguarded moment. If you could flatter him with just the right attention, he might acknowledge his secret self, be coaxed from the closet of denial. 
As evidence, Duncan offers only the reader's own experience watching and listening as he pencils in what the judge/jurisprud may sense only dimly, admit only fleetingly. It is in this way that Duncan's writing is a performance, not a proof.

ACOAFDS is a torrent of simple, straightforward, descriptive sentences mapping the everyday experiences of legal professionals: "they constantly... work ... to shape ... the necessity that they are supposedly merely submitting to."

What we mean by [an] "easy" [case] is that there is a rule that obviously applies to the facts, given some explicit or implicit combination of deductive and policy arguments. From the point of view of the person whose ideological preference is for the obvious rule, the case is easy. From the point of view of the person who thinks the rule unjust, this is a hard case in the sense that it will be difficult, it may take a lot of work, and it may be impossible to displace the obvious solution.?

You recognize the activity instantly, but the description is not the actor's own, and not yet yours. There is something enticing in the view-at first it sounds cynical, but he seems so earnest and diligent, reporting at great length, often going far beyond what would be required to bond cynically with his reader. It sounds critical, says its leftist, but there is much more "taking seriously" than would be required to bond politically with the reader. ACOAFDS offers a seduction more complicated than cynical winks and solidarity hugs.

There are lengthy asides, sure dead ends treated faithfully as possible autoroutes out. The two of you, reader and Duncan, come upon an argument fragment you would have easily dismissed as unpersuasive. But Duncan plays the moral idiot-dismiss? Why exactly, what is your claim, do you think its plausibility has been disproved? And then he renders the fragment strangely plausible, if only for a few paragraphs before it is set aside, not disproved, but ultimately unpersuasive, even in Duncan's hands, as a description of what these people are actually experiencing. And so you too set it aside, this time tentatively-something you were sure you had already rejected out of hand and for a good reason, even if you couldn't quite remember what the reason was.

If Duncan has his way, you set it aside now not because it was "wrong" and you are "right," but because you experience its claim to rightness, once Duncan has restated it, as "a structural element in a disciplinary society," ${ }^{\circ}$ and you feel a flooding up of

\footnotetext{
6 Id. at 369.

7 Id. at 166.

$8 \mathrm{Id}$. at 364.
} 
"contradiction, irony, alienation, despair, and so on" when you hear it. "[R]ather than putting a new theory in place, it [I] looks to induce, through the artifactual construction of the critique, the modernist emotions associated with the death of reason-ecstasy, irony, depression, and so forth." 10 Well, that's always fun. And this refusal of proof and rightness puts Duncan in an oddly generous posture toward those you encounter wandering among the notables. Which brings us to:

\section{DUNCAN AND OTHER PEOPLE}

Duncan plays well with others. In his world, no one is a bad person, almost everyone is trying his or her best, doing well, working hard. He dismisses as uninteresting judges who have "little talent or inclination for legal work"11 or who "repress or have never acquired the ability to strategize."12 For those worth his attention, the idea is to grasp them whole. In the 1970s, we would have said to grok their situation, or get their gestalt; not how they got here or what caused them, but how they really are.

And they really are human, more complex than their arguments, more quixotic than their causes. In this world people are hard to connect with, and this is no easy solidarity. But if people are hard to love, they are also hard to diss. Your own cynicism, your effort to bond with Duncan by ridiculing one or another struggling notable, places you on the operating table, your cynicism itself symptom, an overstatement, a denial, an apologynot at all "what's really going on." Like a patient who arrives late for therapy, you know you will have to spend the next fifty minutes exploring your motivation for rejecting our poor judge or floundering jurisprud.

And yet, somehow, when Duncan describes legal work, it doesn't sound good. For one thing, the people in Duncan's map are hardly the individuated snowflakes of conventional humanism - they are, like so many of us, cartoon characters, types, models, examples. For another, there is bad faith everywhereand there are bad consequences all over the place, made plausible, sustainable, desirable by all this bad faith activity among the elites. The evils here are not conspiracy and deception, but mendacity, denial, refusal to see, over- and underestimating when they also know better. These notables are willing themselves to power behind a veil of ignorance, manufacturing, defending, and

\footnotetext{
$9 I d$. at 346.

$10 \mathrm{Id}$. at 342 .

11 Id. at 181 .

12 Id.
} 
legitimating all sorts of bad outcomes, the biases of a thousand blind spots.

In short, these elites refuse to see themselves and their activity as Duncan-and perhaps by now his reader-sees them: in an analyst's mirror. Theirs is a failure of the self, neither caused by an evil depth nor refutable on the argumentative surface. Their crime is to have terminated their own analysis, to have stood up from the couch and refused to see themselves as they see others. When the reader shares Duncan's picture of the elite's own sentiments, looks on them by the light of his description, their half-gestures, feints, and follies suddenly take shape as bad faith with bad consequences.

How does ACOAFDS provoke this flood of fellow feelings? The voice is relentlessly pop-psychological. And yet, Duncan seems uninterested in the establishment's moral mental health except when he speaks about students or young lawyers learning the ropes. It seems he comes less to cure the elite than to demobilize it by placing the reader before the mirror of his analytic performance. The reader is not always standing alongside Duncan as he develops his photo-the reader also feels himself standing there saying "cheese." Indeed, it would be hard not to find yourself drifting from time to time into identification with the poor judge, sharing, if only for a moment, a pleasing professional fig leaf or two.

At such moments, Duncan's descriptions can touch like dry ice, for his are cold eyes. He can be hurt that you have left his audience and strayed on stage with the others, and he can also thrill to have found you among those who do not yet see clearly. I have opened your one eye, why do you leave the other closed? In Duncan's world, bad faith is not blind, but neither can it see clearly. It sees dimly, rarely, accidentally, a myopic who chronically forgets to put in his contacts or take off his shades. And along comes Duncan with a bright light. ACOAFDS offers itself as a tonic against professional neuroses-to see like this, to foreground this and bracket that, is to avoid bad faith. He sees you when you backslide. It is a voice spoken that it might be introjected.

\section{Pleasure and The Dilemmas of Being DUNCAN'S STUDENT}

There is also pleasure here, entertainment. ACOAFDS is a fun book, by turns playful, ironic, sardonic, sometimes just overthe-top. 
What makes this judge bipolar is that he has a consistent tendency to alternate between ideologies over time.... But like the difference splitter, we predict his behavior on the basis of our knowledge of other people's ideological productions.... Unlike the difference splitter, he "lets himself go" and participates actively in constructing the very ideological positions of which he is at the same time "independent."13

Ahh, I know them like old friends, the difference splitter, the bipolar judge, the (constrained) activist; it is fun to look on with Duncan at their routines, to share the clarity of his catalog, to navigate by his map.

But being mapped can also be pure pleasure. It can even be worth the bad faith. Of course it is nice in reading ACOAFDS to find oneself securely on the side of the introject, gazing out with Duncan at a world of over- and underestimators. But who has not also felt jealous of the analysand, lying there, blabbing on, riveted in the high beam of Duncan's outre performance? The performance is not seductive-it's better than that, a fan dance that pierces your veil and reflects you back at twice your normal intensity. If you forget your introject and suddenly find yourself up on the screen, Duncan's posture shifts from calm description, backward first, drawing you out, quizzing you up; it's great, even if you've been this way many times and know what's next, the abrupt in your face engagement, a kind of dental intimacy.

Many of Duncan's students are figured in the book, our work earnestly and seriously and safely and correctly restated, fit gracefully into his project, snugly, with real paternal warmth. Duncan is a great storyteller; he tucks everything he has heard or seen somewhere into the narrative. The more exotic, the better. If he had once had a student interested in giraffes, the giraffes would be there, plodding about with the difference splitters and bipolar judges. There is something shepherd-like here, plaiting back together all the loose ends of his meandering sheep.

Duncan has a great talent for persuading you that whatever he has been reading is just what should have been read, abruptly interpolating your stray observations into some precursor you never heard of. But he also abhors precursors the way nature abhors a vacuum. It is successors he doesn't seem to mind; no anxiety of influence when his followers can be placed in the narrative, responsible for one or another little point-it's great to get into the story this way.

But what is that compared to the ferocious relentlessless, recklessness, of his attention to the meanderings of the mid- 
century judge? Duncan tells us "it can be pretty infuriating to be treated this way," ${ }^{14}$ but I wonder. I'm sure some days one just hopes to split that difference and be left alone. But it can also be delicious to be seen as your better self knows you are, to have been worth all the attention of a well-educated analyst, even if you are paying him in the currency of your own bad faith.

Many of us remember Duncan looking at us once that way, blunt mute objects that we were, unselfconscious speakers of the professional argot. Those were terrific times, a tennis volley you never wanted to stop. Even if it meant not scoring-even if it meant losing again and again. How flattering to be brought into self-consciousness, my consciousness worth all that serving and returning and running about the court.

ACOAFDS speaks to its readers, to us, as a fallen people, people who know, or once knew. After. Post.

We don't get to the point of psychologizing American judges until we have decided that ... there's no sense in continuing our investigation of their views on the merits ... and ... no sense in further dialogue with them on their own terms, because, for the moment, it is more interesting to figure out why they say what they say .... ${ }^{15}$

The virus of criticism has been roaming loose for years; our notables make virtues from the vices of doubt and unbelief. We see dimly and hide coyly, even as we offer dialog and perform our views of the merits seriously, weightily, confident we deserve all we have become. Perhaps we did know, perhaps Duncan even taught us, but it is also nice to forget. And when we do, it can be fantastic to be seen through. Perhaps the result will be wisdom, if not amusement. I think Duncan's colleagues in the academy like it, judges like it, faculties like it. I know I like it. To be spotted, disrobed, rebuked can also be to be raised up, mature now, a man with a plan, a project, perhaps even a canal.

All of which takes us to the last part...

\section{POLITICS AND THE DILEMMAS OF BEING DUNCAN'S COMRADE}

Duncan ends the book by describing his project as a collective one, in a tradition. And many of us here have been recruited into that project at different times. How does that work, what have we been recruited to? Let's say you introject the book, succeed in joining Duncan on the hilltop, looking out at the crowd of legal

14 Id. at 198.

15 Id. 
notables, come to share his description. You will have gone off screen, an adult, his light no longer shining on your moments of folly. There's a gain and a loss. He's very loyal, and you can now produce descriptions that aim to get you into the next book. But he will never look at you the way he did that first day, and, for all the pleasure of being locked in his beam, you won't want him to.

ACOAFDS expends itself in just that way. Say the performance is persuasive, what is one supposed to do exactly-go off and stare people in the face and tell them what they really look like? Hardly a program for the progressive left. There has always been something retro about Duncan's political projectsremember when he used to make banners and stuff mailboxes and carry signs around? There was always something vaguely ridiculous, something proudly self-mocking in the gesture.

So what are the politics here, exactly? Let's say you have a project, and you start fleshing out a strategic game plan, an ethical justification, start building the political identities and solidarities necessary to get it to happen. Duncan says he's right beside you all the way, but is he really? There are institutional conventions and background solidarities and ideologies. Much seems settled, openings are hard to find, but there are also conflicts and ambiguities and uncertainties. You and your comrades start plotting a course.

As you work in such a field, you are bidding to be a notable, you are over- and underestimating, conjuring identities, elaborating a program. When Duncan takes a stroll with his next student - even perhaps in your head with you as a student, and looks out at your work, you worry that he will see you, as he sees them, and that it won't be pleasurable - why won't he just leave us alone.

I read ACOAFDS as an act, not an argument about what to do. It is odd to hear Duncan retread as an argument, a proposition, a program. Still, I know that Duncan has persuaded many people of his ideas without imparting his sensibility. And perhaps his ideas are helpful, detached from his performanceI've heard it said that they keep us flexible, on our feet, a hyped-up and systematized arsenal of critical maneuvers. ACOAFDS might vaccinate us against the political sirens of program, procedure, principle, and, although they don't start with a $p$, solidarity and identity. On the other hand, this extract of ACOAFDS might also make us soft-a kind of anti-Viagra for the politically committed.

But say we take Duncan as a sensibility, read ACOAFDS as an analytic act-a bringing into consciousness, a performance, in Duncan's terminology, an "artifact." It is an odd performance, 
analysis as lecture, the analysand as reader. But hearing ACOAFDS as an act-come see this with me-rather than as an argument-here's how it is-makes it harder to imagine as a program-always eschew principle, or never deny anything, resist all identity claims.

ACOAFDS enacts an attitude toward the experience of acting like a notable grabbing the ring of governance. Politics has a dark side. For ACOAFDS, it's not the broken eggs or the field of pain and death on which it all proceeds that troubles. This is the stoic ruler, accepting all that distribution, paternalism, violence as a cost of doing business - so long as we notables are not in bad faith. The dark side is the unavoidable faint ridiculousness of politics, the welling up of "contradiction, irony, alienation, despair, and so on."

Here, ACOAFDS offers a struggle of consciousness to be in good faith. And for that, some things simply must be worked out anew each time, can't be turned into a program or an identity, or even into a list of tips and best practices. And for that, a benevolently smirking introject can be a great help.

When we find ourselves working away, struggle ourselves to be and to be in good faith, we will wonder if Duncan will be there, and, if he is, whether he'll be raining on the parade. It turns out he might be there and he might not; he might see through us and he might not see us at all. On your wedding day, Duncan's the kind of guy who wants to be sure that you are completely in touch with the dark side. He wants you to acknowledge the day before you get tenure that it's still too early to tell, that being fired might have its privileges. There is a call here-to see yourself from a great height, to see yourself as your introject might see you. As you have seen the other notables, so shall you see yourself. And yes, that can feel like rain on the big day. For a while when I tried to enlist Duncan in projects, he'd grin and refer to me as "the emperor." But, I must say, he also often made a great lieutenant. Because even when he smirks, he's also likely to be happy for you, and might well come along. But, of course, he also might not.

I, for one, like doing politics with such a person-in person, on paper, in my head. But it makes complete sense that someone might not. I have wondered about the relative silence that has greeted the mature work of one of our leading legal theorists. Perhaps part of the explanation lies here. Duncan speaks about issues at the core of the jurisprudential canon, but he is not in dialogue with others in conventional terms. He says it will be 
"more interesting to figure out why they say what they say,"16 and it is. But the term "interesting" does a lot of work here-more fun, more useful, more progressive, more what, exactly? ACOAFDS presents itself as an artifact and offers an experience. The book gives a performance, a giddy and idiosyncratic reading of the consciousness of the legal establishment. You can introject it. You can reject it. You can just walk on by. Or you can lie back and enjoy it. 
. 